Sympozjum

Rok XXIII 2019, nr 2(37), s. 117-140

\author{
ks. Janusz Królikowski \\ Uniwersytet Papieski Jana Pawła II w Krakowie \\ ORCID: 0000-0003-3929-6008; e-mail: jkroliko@poczta.onet.pl \\ https://doi.org/10.4467/25443283SYM.19.026.11428
}

\title{
MARYJA „TYPUS ECCLESIAE” \\ I EWANGELIZACJA
}

\author{
MARY „TYPUS ECCLESIAE” \\ AND THE EVANGELISATION
}

\begin{abstract}
Abstrakt
W nauczaniu II Soboru Watykańskiego zostało wyraźnie podkreślone, że teologia i życie Kościoła potrzebują stałego odniesienia do Maryi. W szczególny sposób wyraża tę potrzebę zastosowane do Maryi miano typus Ecclesiae, którym określali Ją już ojcowie Kościoła. Niniejszy artykuł stanowi próbę odniesienia tego określenia do ewangelizacji w Kościele, aby nadać jej także maryjny charakter. Wydaje się, że można do Maryi zastosować miano „typ ewangelizacji”, ponieważ w Jej wierze i w wynikających z niej kluczowych postawach znajdujemy takie elementy, które pozwalają nadać ewangelizacji bardzo określoną strukturę. Można więc także zasadnie postulować, aby ewangelizacja w Kościele była prowadzona w oparciu o maryjną strukturę.

Słowa kluczowe: Maryja, Kościół, typus Ecclesiae, ewangelizacja, wiara, łaska, pokora
\end{abstract}




\section{Abstract}

The teaching of Second Vatican Council clearly emphasised that theology and the life of the Church are in need of constant reference to Mary. This need is especially manifested in the name typus Ecclesiae applied to Mary, which was already used by the Church Fathers. This article attempts to apply this name to the evangelisation in the Church, in order to make it Marian in character as well. It seems that the notion of "the type of evangelisation" can be applied to Mary, since in Her faith and in the key attitudes resulting from it we can find such elements which allow us to shape evangelisation according to a strictly defined structure. Therefore, it is justified to say that the evangelisation in the Church should be conducted according to Marian structure.

Keywords: Mary, Church, typus Ecclesiae, evangelisation, faith, grace, humility

Zagadnienie nowej ewangelizacji, postulowanej już pod koniec lat siedemdziesiątych przez kard. Stefana Wyszyńskiego, za sprawą papieża św. Jana Pawła II nabrało stopniowo znaczenia dla całego Kościoła, także dla Kościoła w Polsce. Za sprawą papieża Benedykta XVI nowa ewangelizacja przybrała wymiar instytucjonalny; także papież Franciszek daje do niej coraz to nowe impulsy. Te ważne fakty sprawiają, że zarówno ewangelizacja, jak i ten jej element, który nazywamy „nową”, domagają się dalszej, mocno zaangażowanej refleksji teologicznej, aby ewangelizacja mogła zostać skutecznie przełożona na język praktyki kościelnej ${ }^{1}$. Gdy mówimy o nowej ewangelizacji, chodzi nam zatem o wypracowanie odpowiedniej wizji teologicznej, przekładającej się potem na aktualne normy praktyczne i programy duszpasterskie dotyczące działania ewangelizacyjnego, odpowiadającego sytuacji duchowej naszych czasów; chodzi także o normy operatywne, które nie gaszą ducha, ale go efektywnie pobudzają i ukierunkowują podejmowane przedsięwzięcia. Normy i pro-

1 Por. R. Fisichella, La nova evangelizzazione. Una sfida per uscire dall'indifferenza, Milano 2011. 
gramy nie rozwiązują samoczynnie zasadniczych problemów, przed którymi staje dzisiaj Kościól, ale bez nich nie da się adekwatnie zmierzyć $\mathrm{z}$ istniejącą sytuacją eklezjalną, domagającą się realistycznego opisania i twórczego zaangażowania apostolskiego, ewangelizacyjnego i misyjnego. Już sama wielość przymiotników, które opisują postulowane dzisiaj zaangażowanie kościelne, pokazuje, że mamy do czynienia z rzeczywistością, która domaga się zdecydowanego uwzględnienia i szerokiego przełożenia na język faktów eklezjalnych.

W działalności upływającej pod znakiem nowej ewangelizacji, podobnie jak w każdej dziedzinie zaangażowania kościelnego, widzimy także konieczność odniesienia do Maryi. Wynika to przede wszystkim z tej racji, że dzięki Niej zyskujemy lepsze i głębsze rozumienie Kościoła, czego dowodzi II Sobór Watykański i ukierunkowana eklezjalnie mariologia posoborowa, a zatem domaga się odniesienia do Maryi misja historyczna Kościoła oraz szukane i proponowane sposoby jej urzeczywistniania. Nie jest więc przypadkiem, że także w dziedzinie nowej ewangelizacji, będącej przynajmniej pod pewnymi względami nowym aspektem ewangelizacji kościelnej, szukamy takiego jej rozumienia, które uwzględniałoby także wątki maryjne. Zawsze, ilekroć panował zamęt w świecie, zwracano się do Kościoła, domagając się, aby on swoją autentycznością duchową włączył się w przywracanie zagubionego porządku i sensu. Stałym elementem tej autentyczności i jej wyrażania się w poszczególnych epokach był przystosowany do pojawiania się nowych okoliczności duchowych, odpowiednio uzasadniony teologicznie, kult maryjny.

Nowa ewangelizacja postulowana w Kościele, a także doceniana poza nim, jest elementem odkrywania jego autentycznego wkładu w życie świata, którego zasadą naczelną pozostaje odniesienie do Boga i jego faktyczna jakość. Na ogół każda nowa epoka szuka nowego Kościoła nowego, oczywiście, a także optymalnego w sensie ewangelicznym. Najlepiej wyraża to teologicznie pojęcie „nieustannej odnowy” - jak stwierdza konstytucja Lumen gentium² ${ }^{2}$ Tę potrzebę musimy przemyśleć przede

2 II SoBór WATYKAŃsKi, Konstytucja dogmatyczna o Kościele Lumen gentium, Rzym 1964 (dalej: LG), 8. 
wszystkim w samym Kościele. Narzuca tę potrzebę, w gruncie rzeczy mającą bardzo starożytną metrykę, Kościołowi jego natura oraz jego misja zbawcza w świecie. Refleksja nad samą istotą Kościoła może i powinna mieć wpływ na to, co najogólniej nazywamy duszpasterstwem lub praktyką, czyli ewangelizacją, jak dzisiaj chętnie mówimy. Nie można jednak autentycznie mówić o naturze i misji Kościoła bez spojrzenia na Maryję, ponieważ jest Ona zarówno „pierwszą chrześcijanką”, „pierwszym Kościołem”, jak i Kościołem w jego wypełnieniu eschatologicznym „obrazem Kościoła chwalebnego"3.

W tym miejscu należy wspomnieć również, że nieodzownym elementem ewangelizacji jest podjęcie pokornej autokrytyki w odniesieniu do wielu dotychczasowych działań kościelnych. Doświadczenie jednoznacznie podpowiada, że w wielu przypadkach w Kościele bardziej ufamy odziedziczonym i utrwalonym, historycznym schematom działaniowym niż autentyczności ewangelicznej i wyznaczonym przez nią drogowskazom. Nie są ważne w tym miejscu powody, dla których tak czynimy, czyli przede wszystkim dominująca mentalność - ważna jest konieczność namysłu nad tym, co czynimy, aby objąć wszystko duchem wiary i w jej świetle pytać o treść i sens naszych działań. Weryfikacja ewangeliczna wielu aspektów naszej praktyki pokazuje nam pilną potrzebę ewangelizacji prowadzonej w nowym duchu, nowymi metodami i z nowym zapałem. Duch maryjny jest na pewno także duchem weryfikacji ewangelicznej codziennego życia i podejmowanych działań zarówno indywidualnych, jak i eklezjalnych.

W proponowanym tutaj ujęciu zagadnienia odwołamy się przede wszystkim do zakorzenionego już w tradycji patrystycznej określenia typus Ecclesiae, które zostało przypomniane w nauczaniu na temat Maryi Bogarodzicy w tajemnicy Chrystusa i w tajemnicy Kościoła, które w czasie II Soboru Watykańskiego sformułowano w VIII rozdziale konstytucji dogmatycznej Lumen gentium: „Błogosławiona Dziewica z racji daru i roli Boskiego macierzyństwa, dzięki czemu jednoczy się z Synem Odkupicielem, i z racji swoich szczególnych łask i darów jest głęboko zwią-

\footnotetext{
3 Por. LG 68.
} 
zana także z Kościołem: Boża Rodzicielka jest, jak uczył już św. Ambroży, pierwowzorem (typus) Kościoła w porządku wiary, miłości i doskonałego zjednoczenia z Chrystusem. W misterium bowiem Kościoła, który sam także słusznie jest nazywany matką i dziewicą, Błogosławiona Dziewica Maryja idzie przed nami, stanowiąc najdoskonalszy i jedyny wzór zarówno dziewicy, jak i matki. Wierząc bowiem i będąc posłuszną, zrodziła na ziemi samego Syna Boga Ojca, i to nie znając męża, ocieniona Duchem Świętym, niby nowa Ewa, która nie dawnemu wężowi, lecz wysłannikowi Boga okazała wiarę nie skażoną żadną wątpliwością. Zrodziła Syna, którego Bóg ustanowił pierworodnym między wielu braćmi, to znaczy między wiernymi, w których zrodzeniu i wychowywaniu współdziała w macierzyńskiej miłości”" ${ }^{4}$.

\section{Maryja typus Ecclesiae}

Co daje Kościołowi spojrzenie na Maryję? Patrząc na Nią jako żywą i konkretną osobę, doskonale pełniącą zleconą Jej misję w boskim zamyśle zbawienia, dochodzi się przede wszystkim do rozumienia żywego i konkretnego Kościoła, którego nie pozwala wystarczająco osiągnąć refleksja oparta wyłącznie na abstrakcyjnych pojęciach. Niestety, liczne wypowiedzi na temat Kościoła, nawet najbardziej teologiczne i zrównoważone, są naznaczone wpływami myślenia abstrakcyjnego, które sprawia, że jest on bardziej pojęciem niż rzeczywistością historyczną. Oczywiście, Kościół potrzebuje pełnego i systematycznego opisu teologicznego, w którym wykorzystuje się odpowiednio ścisłe pod względem treściowym pojęcia, ale nie można zapomnieć, że Kościół jest budowany przez Chrystusa Zbawiciela z żywych osób, których uczestniczenie w Kościele opiera się na wierze i zmierza do pełnej wolności w miłości, której źródłem jest łaska, również udzielana w Kościele i przez Kościół. Każda wypowiedź na temat Kościoła musi przynajmniej pośrednio zakładać ten fakt, aby ustrzec się mówienia o nim jako o rzeczywistości obcej i odległej od ludzkich doświadczeń.

\footnotetext{
${ }^{4}$ LG 63.
} 
Już św. Ambroży z Mediolanu, na którego powołał się II Sobór Watykański, zastosował do Maryi określenie typus Ecclesiae, a po nim szeroko uwzględnił je w swoim nauczaniu św. Augustyn, czyniąc z niego kryterium teologiczne zarówno w spojrzeniu na Maryję jako „pierwszą chrześcijankę", jak i w spojrzeniu na Kościół, czego dowodzi zwłaszcza wydobycie w nim aspektu duchowego, dziewiczo-macierzyńskiego w stosunku do wiernych. Określenie typus Ecclesiae, złożone w swoim znaczeniu biblijno-teologicznym, należałoby przetłumaczyć na język polski jako „praurzeczywistnienie Kościoła”. Samo proste tłumaczenie łacińskiego (greckiego) pojęcia typus jako „wzór” jest niewystarczające, ponieważ zakłada jedynie pewne odniesienie moralne tego pojęcia. Jego pierwotne znaczenie ma jednak zdecydowanie szersze odniesienia, a mianowicie podkreśla, że wzór, na który się nim wskazuje, posiada obiektywne i jednoznaczne zakorzenienie ontologiczno-personalne. „Typ” wskazuje na to, co ma charakter pierwotny i oznacza rzeczywistość już autentycznie spełnioną, dzięki czemu może ona potem pełnić funkcję ogólnie przyjmowanego i zobowiązującego wzoru. Maryja w sobie, w swojej osobie i w spełnionym dziele, urzeczywistnia się jako Kościół, dzięki czemu może być także uznana za wzór jego kształtowania się wewnętrznego i jego oddziaływania zewnętrznego. Tradycja kościelna bardzo jednoznacznie interpretuje tę zależność, gdy niemal od samego początku utożsamia ze sobą Maryję i Kościół ${ }^{5}$. Zwłaszcza tradycja patrystyczna jest pełna obrazów i metafor, które zmierzają do wydobycia i ukazania tej zależności, a następnie także do wyprowadzenia z niej aspektów wzorczych. Izaak ze Stella, średniowieczny teolog, bardzo trafnie podsumował tradycję patrystyczną, stwierdzając: „Matką jest i Maryja, i Kościół. I obie są dziewicze. Tak jedna, jak druga bez udziału żądzy ciała poczęły z tego samego Ducha Świętego i obie dały potomstwo Bogu Ojcu. Maryja bez żadnej zmazy zrodziła ciału głowę, a Kościół w odpuszczeniu wszystkich grzechów daje tej głowie ciało. I Maryja, i Kościół to Matka Chrystusa, lecz żadna z nich nie rodzi Go całego bez drugiej. Dlatego wszystko, co w pis-

${ }^{5}$ Por. H. RAhner, Maria e la Chiesa. Indicazioni per contemplare il mistero di Maria nella Chiesa e il mistero della Chiesa in Maria, Milano 1991. 
mach natchnionych przez Boga ogólnie powiedziano o Dziewicy-Matce, ogólnie też odnosi się do Kościoła, a szczególnie do Maryi. To zaś, co się tam mówi specjalnie o Dziewicy-Matce, Maryi, w ogólnym znaczeniu stosuje się również do dziewiczej matki, Kościoła; a to, co tam powiedziano o jednej z nich, dotyczy łącznie ich obu"6.

Ścisłe związanie postaci Maryi z Kościołem od starożytności wywiera znaczący wpływ na eklezjologię, przede wszystkim kształtując jej osobowy i duchowy wymiar, choć niewątpliwie wywiera zarazem ono wpływ na samą mariologię, chroniąc ją przed popadnięciem w sentymentalizm i przed oddzieleniem jej od wiary, a zwłaszcza od jej osobowego i konkretnego przeżywania oraz od formowania jej w duchu kościelnym. Maryja jako osoba żywa, wierząca i działająca, ukazuje, że Kościół nie jest rzeczywistością statyczną - urzeczywistnia się on i postępuje w dziejach, kształtując konkretnych wierzących, a tym samym kształtując się jako organiczna całość (Ecclesia catholica). Oprócz Maryi, Dziewicy i Matki, nie ma nikogo, kto mógłby przeżyć i wyrazić autentyczną i pełną istotę kościelnej odpowiedzi na zbawcze działanie Boga.

W świetle Nowego Testamentu istnieje podstawowa droga, która prowadzi od chrystologii do eklezjologii, dlatego też jest w nim wyraźnie obecna droga prowadząca od mariologii do eklezjologii, skoro mariologia rozwija się jako organiczna część chrystologii. Widzimy to zwłaszcza w Ewangeliach św. Łukasza i św. Jana, chociaż nie zapominamy o 12 rozdziale Apokalipsy, który wprawdzie pierwotnie posiada znaczenie eklezjologiczne, ale już u wielu ojców Kościoła zyskał interpretację eklezjalno-maryjną. Chrystologia, w swojej konkretnej treści syntetyzująca dzieje zbawienia, jest więc mariologią, gdyż Słowo Boże, które stało się ciałem, pochodzi również od Maryi, gdyż wcielenie stanowiące część dziejów zbawienia, dokonało się w wierze i w ciele Maryi (natus de Maria Virgine). Mariologia jest zaś zarazem eklezjologią, ponieważ Maryja, rodząc Jezusa Chrystusa, zrodziła Głowę Kościoła, stając w ten sposób u początku

${ }^{6}$ IzaAK z Stella, Kazanie 61 (na Wniebowzięcie), cyt. za: H. DE Lubac, Katolicyzm. Społeczne aspekty dogmatu, tłum. M. Stokowska, Kraków 1988, s. 184. 
Jego misji zbawczej, która w ciągu wieków uobecnia się w Kościele7. Zbawcza tajemnica wcielenia Syna Bożego, w którym czynnie uczestniczy Maryja, Dziewica i Matka, posiada bezpośredni i wewnętrzny związek z Kościołem, zarówno z jego narodzinami, jak i z jego urzeczywistnianiem się w dziejach.

\section{Maryja „typ” ewangelizacji}

$\mathrm{W}$ niniejszych refleksjach chodzi przede wszystkim o pokazanie zarysu podejmowanego tematu oraz jego ukierunkowanie, wychodząc od pełnej realizacji eklezjalnej współdziałania Boga i człowieka, które doskonale urzeczywistniło się w Maryi. W gruncie rzeczy Kościół w swojej istocie nie jest niczym innym niż takim właśnie współdziałaniem, które jest źródłem i historycznym wypełnianiem dzieła zbawczego dokonanego przez Jezusa Chrystusa. Wszystko, czym żyje Kościół historyczny i do czego zmierza, znajduje w takim współdziałaniu swoje centrum i zasadę swojego urzeczywistniania się w dziejach. Wszelka działalność apostolska, ewangelizacyjna i misyjna zmierza do tego, by takie współdziałanie wzbudzić, a potem je utrwalić, aby mogło zostać historycznie dopełnione Chrystusowe dzieło zbawienia. Chodzić więc nam będzie przede wszystkim o wskazanie na maryjną „koncentrację" tego współdziałania, które - ponieważ osiągnęło swój pełny kształt w Maryi - może posiadać dla Kościoła wzorcze znaczenie oraz stanowić pewny punkt odniesienia. Temat związku Maryi z ewangelizacją mógłby, oczywiście, zostać potraktowany o wiele szerzej, a może nawet dałoby się wypracować jakiś "model” nowej ewangelizacji prowadzonej w duchu maryjnym. Jest to jednak zadanie na przyszłość, chociaż nie należałoby go zbytnio odkładać, biorąc pod uwagę pilne potrzeby w tym względzie. Warto może z pewnym niedosytem zauważyć, że w ostatnich latach powstało wiele grup i zespołów ewangelizacyjnych, które inspirują się rozmaitymi postaciami biblijnymi, ale - na ile mi wiadomo - nie ma dotychczas

7 Por. J. KRólikowski, Kościół w Jezusie Chrystusie. Chrystologiczno-pneumatologiczna geneza Kościoła, Kraków 2015, s. 27-54. 
żadnej inicjatywy ewangelizacyjnej, która wprost inspirowałaby się Maryją, która nie przypadkiem, począwszy od pontyfikatu św. Pawła VI, jest nazywana „Gwiazdą ewangelizacji”.

\section{Maryja arcydziełem odkupienia ofiarowanego i przyjętego}

Wszystko, co dokonało się w Maryi, przede wszystkim Jej boskie macierzyństwo, zakorzeniając się oczywiście w udzielonej Jej „pełni łaski” (Łk 1,28), wyrasta z Jej osobistej wiary (fiat) i na wierze się koncentruje - wiara kształtuje Jej osobowe wyrażenie się wobec Boga i wobec świata oraz prowadzi Ją do jedynego w swoim rodzaju i doskonałego udziału w dziejach zbawczych. O osobie Maryi i o spełnieniu się Jej osobowości nie decyduje biologia i psychologia, ale akt wiary, a następnie wydarzenie, które w oparciu o niego się rodzi i urzeczywistnia, wpisując się organicznie $w$ dzieje zbawienia sprawiane przez Boga. Nie jest to jednak epizod prywatny, który odnosiłby się tylko do Maryi, ale posiada on funkcję publiczną i oficjalną, ponieważ należy integralnie do dziejów zbawienia rozumianych w sposób pełny. Przedmiot i cel tego aktu dotyczy wprost wcielenia wiecznego Słowa, w którym dokonuje się odkupienie ludzkości, które osiągnie swoją pełnię w Jego krzyżu i w zmartwychwstaniu. Należy jednak zawsze pamiętać, że przyjście Słowa w ciele poddanym grzechowi jest już samo przez się decydującym czynnikiem odkupienia, ponieważ z niego wyłoni się potem jego pełne i definitywne urzeczywistnienie.

Maryja, jako ta, która miała począć zbawienie świata aktem równocześnie osobistym i oficjalnym, sytuuje się w centralnym i decydującym punkcie dziejów zbawienia. Może być uznana za ich „syntezę”, jak stwierdził św. Jan Damasceński ${ }^{9}$. Współdziałanie Maryi w odkupieniu jest aktem osobowo-duchowej akceptacji, „przyjęcia”, jak dzisiaj chętnie mówi-

${ }^{8}$ Por. Tenże, Maryja - Gwiazda ewangelizacji, w: Idźcie i głoście. Przez Chrystusa, $z$ Chrystusem, $w$ Chrystusie. Przez wiare i chrzest do świadectwa. Program duszpasterski Kościoła w Polsce na lata 2013-2017, Poznań 2016, s. 353-369.

9 Por. Jan Damasceński, De fide orthodoxa 3, 12: PG 94, 1029C: „Samo imię Matki Boga zawiera całą tajemnicę ekonomii Wcielenia”. 
my w mariologii, konkretyzującym się w poczęciu Jezusa. Nie jest to akt, który miałby swoje źródło w Jej inicjatywie, nie jest Ona jego autonomiczną i pierwotną sprawczynią, ale jest w nim Służebnicą Pańską (Łk 1,38). Jest to akt, który w najwyższym stopniu urzeczywistnia się na mocy odkupieńczego działania sprawianego przez Boga i z tej racji jest on decydujący dla zbawienia świata. W szerszym znaczeniu jest to akt wpisany w nasze dzieje - w dzieje naszego zbawienia, dlatego dotyczy on spotkania się dziejów łaski, urzędu i osoby, misji oficjalnej i charyzmatu, znaku i rzeczywistości oznaczanej. W Maryi doskonale i absolutnie zbiegają się, a nawet nierozdzielnie nakładają na siebie, misja oficjalna i realizacja osobista, chociaż nie utożsamiają się ze sobą. W Maryi widzimy więc arcydzieło działania odkupieńczego, polegającego na łaskawym udzielaniu się Boga i jego ofiarnym przyjęciu przez człowieka.

Jeśli zatem Kościół nie jest niczym innym niż zgromadzeniem odkupionych przez całkowicie darmową łaskę Jezusa Chrystusa, ale historycznie widzialnym, mającym swój centralny punkt w dobrowolnym przyjęciu Go, zarówno w ciele, jak i w duszy, to Maryja jest tym samym najwyraźniejszym i najwymowniejszym szczytem organizmu kościelnego. Z tej racji jest Ona właśnie w najwyższym stopniu typem Kościoła, czyli jego praurzeczywistnieniem, ponieważ w Niej dokonuje się wyjątkowe spełnienie odkupienia czynnego i biernego, obiektywnego i subiektywnego, charakteryzujące się absolutną czystością oraz niekwestionowaną jedynością. W Maryi łaskawe udzielanie się Boga i Jego pełne przyjęcie w wolności wiary stają się wydarzeniem osobowym i historycznym, ale posiadającym także znaczenie uniwersalne i instytucjonalne. Dzięki temu Maryja jest także tym szczęśliwym stworzeniem - zrodzonym i ukształtowanym przez łaskę Bożą - które przyjmuje tę łaskę zarówno dla siebie, jak i dla wszystkich. Przez osobistą wiarę nawiązuje oblubieńczą więź z Bogiem w imieniu całej ludzkości, która w Niej się uobecnia i wypełnia, czego przedłużeniem stanie się Kościół-oblubienica, będący równocześnie Kościołem-instytucją. 


\section{Maryja wzorem apostolatu}

Maryja została nazwana Królową Apostołów, Królową wyznawców, a dzisiaj jest nazywana Gwiazdą ewangelizacji i Gwiazdą Kościoła ewangelizującego. Jest Ona typem działalności apostolskiej, misyjnej i ewangelizacyjnej i jest nim w całej prawdzie. Życie Maryi oparte na łasce Bożej jest pierwszym wydarzeniem ewangelizacyjnym, w stosunku do którego każde działanie zmierzające do ewangelizacji jest tylko bladym cieniem, a każde późniejsze, autentyczne działanie ewangelizacyjne zawsze ma w nim jakiś udział. Z osoby i działania Maryi można więc wyprowadzić, czym jest i czym powinna być ewangelizacja. Nie jest ona jedynie jakimś abstrakcyjnym ideałem, który usiłuje się przekazać i do niego przekonać, aby na nim móc potem oprzeć życie, ale jest realnym wydarzeniem skutecznym i wzorczym, którego sens jest bardzo jednoznaczny i wymowny - oznacza on pełne przyjęcie Boga dokonującego odkupienia człowieka. Wprawdzie to wydarzenie jest uwarunkowane osobowo i historycznie, jak konkretna jest osoba Maryi z Nazaretu, ale zarazem jest całkowicie konkretne i organicznie wpisane w ramy uniwersalne, nawet jeśli jest niepowtarzalne w całościowych dziejach odkupienia człowieka ani nie może być naśladowane w swojej głównej treści, czyli w Bożym macierzyństwie, w którym pełna wiara Maryi przenika się na zasadzie wzajemnej wymienności z pełnią zstępowania Boga (synkatabasis) do człowieka $^{10}$. Właśnie w swojej jedyności historycznej dzieło ewangelizacyjne Matki Słowa wcielonego jest wzorem żywotnym i zawsze aktualnym.

Dzieło ewangelizacji prowadzone w Kościele i przez Kościół domaga się więc czegoś w rodzaju nieustannej anamnezy maryjnej, której pierwszym przedmiotem będzie uczestniczenie Maryi w tajemnicy zbawienia. Dzięki temu także misja i działanie Kościoła będą mogły zyskać rysy maryjne, aby dokonywać nowej aktualizacji historycznej zbawczego działania Boga. Warto zwrócić tutaj uwagę na dwa zasadnicze rysy maryjnej wzorczości w stosunku do dzieła odkupienia.

10 Por. C. Scaglioni, Synkatabasis. La condiscendenza divina in Giovanni Crisostomo, Trapani 2011. 
Wiara Maryi jest więc przede wszystkim oparta na uznaniu, że Bóg działa na rzecz człowieka i to działanie urzeczywistnia się w świecie faktów i wydarzeń. Jest cechą charakterystyczną wiary biblijnej, iż uznaje ona w pełni realne zniżanie się Boga do świata, otwiera się egzystencjalnie na Jego bliskość osobową i historyczną, jest gotowa przyjąć Go w konkretności codziennej egzystencji. Boże macierzyństwo Maryi pokazuje, że działanie Boga idzie tak daleko, że staje się faktem biologicznym, a tym samym także w najbardziej właściwym znaczeniu faktem historyczno-kulturowym. Z punktu widzenia ewangelizacji oznacza to przede wszystkim oparcie się na tym fakcie wyrażane w takim ukazywaniu tajemnicy Boga i Jego działania, aby ten istotny rys jej obecności historycznej był zawsze stawiany na pierwszym miejscu. Oczywiście, domaga się to odpowiedniego mówienia o obecności Boga i jej możliwości wejścia w życie człowieka i w dzieje świata. Często podkreślane w najnowszej teologii znaczenie historycznego aspektu objawienia i zbawienia powinno być traktowane jako zasadniczy rys chrześcijańskiego obrazu Boga, a tym samym kluczowy element głoszenia chrześcijańskiego.

Dowartościowanie ewangelizacyjne zarysowanego tutaj zagadnienia domaga się przełamania współczesnej mentalności, która stoi niemal na antypodach wiary biblijnej. Jednym z zasadniczych rysów współczesnego obrazu świata jest pozorne wyeliminowanie możliwości działania w nim Boga. Świat zdaje się być tak ściśle opisany twardym reżimem praw przyrody i wzorów matematycznych, że nie dopuszcza on w swojej strukturze już żadnej „szczeliny”, by przez nią Bóg mógł wejść w losy człowieka i świata. Zachodzi więc potrzeba dokonania nowego otwarcia człowieka i świata na Boga, by Jego bliskość wyrażana we wpływie historycznym mogła zostać dostrzeżona i przyjęta.

Wydaje się, że biblijne wypowiedzi o Maryi pokazują nam bardzo wyraźnie, gdzie jest ta „szczelina” egzystencjalna i kulturowa, która pozwala w pewnym sensie przepuścić działanie Boga zniżającego się do człowieka oraz umożliwia jego osobiste przyjęcie. Jest nią wolność Maryi, która nie poddaje się żadnemu opisowi matematycznemu i żadnemu naciskowi jakiegoś prawa zewnętrznego. Wiara, z którą Maryja przyjęła Boga i Jego odkupieńcze działanie, jest w najwyższym stopniu aktem Jej wolności, która została przez łaskę uzdolniona do przyjęcia Boga 
w sposób najpełniejszy i najbardziej konkretny. Ma pełne uzasadnienie zastosowanie do Maryi miana „ikony wolności i wyzwolenia”, które coraz częściej powraca w nauczaniu kościelnym i w teologii ${ }^{11}$. Stanowi ona ważny nurt w teologicznej interpretacji nie tylko osoby Maryi, ale przede wszystkim Jej wiary, a tym samym także wiary ludzkiej w ogóle. Nie chodzi bynajmniej w tym przypadku tylko o podkreślenie, że Bóg nie przymusza do niczego człowieka, ale przede wszystkim o to, żeby pokazać, iż pełnia ludzkiej wolności wyraża się tylko w odniesieniu do prymatu Boga i do osobowego przyjęcia Jego zbawczego działania, które jest w najwyższym stopniu działaniem wyzwalającym: „Ku wolności wyswobodził nas Chrystus" (Ga 5,1).

Jak w przypadku zagadnienia działania Bożego, tak i w tym przypadku stajemy wobec potrzeby przełamania pewnego schematu, czy nawet archetypu nowożytnego, który bezkrytycznie upraszczając i ideologicznie naciskając, głosi, że człowiek może być wolny tylko bez Boga bądź też nawet przeciw Bogu. Schemat ten stawia przed nami zasadniczą potrzebę odnowienia teologii wolności, która opiera się na łasce Bożej, a więc na przyjęciu Boga i Jego działania w stosunku do człowieka. Maryja jawi się tutaj w najwyższym stopniu jako przykład osoby spełnionej osobowo i duchowo, a więc osoby w pełni wolnej, dzięki przyjęciu w wierze Boga i Jego zwycięskiej, a tym samym także wyzwalającej, łaski. Oznacza to, że trzeba bardziej jednoznacznie pokazywać w Maryi Jej aktywność w ścisłej łączności z działaniem Bożym, które nie tylko nie pozbawiło Jej niczego, co ludzkie, osobowe, egzystencjalnie wartościowe i dojrzałe, ale uczyniło pełną osobą, jak pełna była łaska, która została Jej udzielona. Maryja ukazuje w najwyższym stopniu, że „łaska czyni pięknym jak światło", jak stwierdza św. Tomasz z Akwinu ${ }^{12}$, a tym samym także spełnionym osobowo, ponieważ ostatecznie wyzwolonym. Może to być także kluczowa zasada w ramach postulowanej dzisiaj potrzeby rozwijania „drogi piękna” w mariologii.

11 Por. Kongregacja Nauki Wiary, Instrukcja o chrześcijańskiej wolności i wyzwoleniu Libertatis conscientia, Rzym 1986, 97, w: J. Królikowski, Z. Zimowski (red. i tłum.), W trosce o petnię wiary. Dokumenty Kongregacji Nauki Wiary 1966-1994, Tarnów 2010, s. 334; Jan PaweŁ II, Encyklika Redemptoris Mater, Rzym 1987 (dalej: RM), 37.

12 Por. Tomasz z Akwinu, In psalmos Davidis expositio, 25, 5. 


\section{Maryjna struktura ewangelizacji}

Po ukazaniu maryjnego wymiaru Kościoła i pełnionej przez niego misji ewangelizacyjnej, inspirując się nauczaniem soborowym na temat Maryi jako typus Ecclesiae, możemy teraz zwrócić uwagę na niektóre bardziej szczegółowe zagadnienia, w których ten wymiar powinien się niejako skonkretyzować. Możemy w tym przypadku spróbować określić pewną strukturę ewangelizacji, która wynika ze spojrzenia na Maryję w kluczu eklezjalnym. Chodzi o to, by zaproponowany kształt ewangelizacji nabrał charakteru operatywnego i mógł faktycznie być wykorzystywany w działalności ewangelizacyjnej.

\section{„Synteza” wiary i łaski}

Ewangelizacyjne dzieło Maryi pokazuje przede wszystkim wyraźnie ścisłą więź zachodzącą między ewangelizacją prowadzoną przez duchowieństwo i prowadzoną przez świeckich - jest to jedno dzieło wszystkich, z czego już w punkcie wyjścia należy sobie zdać sprawę, zostawiając na boku dochodzące do głosu zbytnie akcentowanie pełnionych funkcji, określanych w swoim wyrazie z punktu widzenia płciowości ${ }^{13}$. Maryja - Królowa Apostołów - nie była kapłanem, ale nie była też tylko osobą świecką. „Ona ma coś innego i coś więcej” (Ipsa aliud et plus habet), jak stwierdził papież Jan Paweł II w liście apostolskim Mulieris dignitatem, cytując wypowiedź Hansa Ursa von Balthasara ${ }^{14}$. Zajmuje Ona całkowicie wyjątkowe i wzniosłe miejsce jako stworzenie odkupione niezależnie od wszelkiego czynnika subiektywnego, jakby niezależnie od Jej współdziałania jako osoby i Jej wszystkich władz duchowych. W Maryi wszystko jawi się w sposób pierwszorzędny jako dar, który pochodzi jedynie od samego Boga całkowicie darmowo działającego w dziejach zbawienia. Mamy tutaj wyraźne potwierdzenie zasady pierwszeństwa daru, która jednoznacz-

${ }^{13}$ Nie bagatelizujemy tego zagadnienia, ale wydaje się, że jest ono dzisiaj zbytnio i jednostronnie akcentowane, co sprawia, że nie określamy naszych ról i zadań eklezjalnych z perspektywy teologicznej, ale tylko z perspektywy antropologicznej, która jest dalece niewystarczająca do mówienia o misji zbawczej spełnianej w Kościele przez jego członków.

14 Jan PaweŁ II, List apostolski Mulieris dignitatem, Rzym 1988, 27. 
nie wyłania się już z tajemnicy stworzenia, a zostaje konsekwentnie potwierdzona w dziejach zbawienia, które w swojej istocie są dziejami samoudzielania się Boga stworzeniu osobowemu. Maryja pozostaje niejako czystym otwarciem na dar samego Boga, czego pierwszym wyrazem jest Jej pokora (por. Łk 1,48). W tym znaczeniu ukazuje Ona jednoznacznie to, co jest wspólne kapłanom i świeckim - wszyscy wyrastają tak samo i pierwotnie z Bożego daru, tym zaś, co wprowadza różnicę, jest tylko sposób jego przyjęcia i manifestowania w konkretnym życiu, chociaż zawsze jest w nim zawarte pewne odniesienie do wszystkich, gdyż każda łaska udzielana przez Boga człowiekowi jest zawsze łaską „braterską”.

Wychodząc z tego fundamentalnego założenia, Kościół zawsze i jednoznacznie dystansował się w stosunku do wszelkiego indywidualizmu duchowego, występował przeciw wszelkim formom laicyzmu antyklerykalnego, zdecydowanie podkreślając znaczenie organizacji instytucjonalnej, hierarchii, sakramentów, czyli tego, co służy obiektywnemu i skutecznemu „pośredniczeniu” darów Bożych w stosunku do człowieka. Jest jednak tak samo prawdą, że Kościół zawsze domaga się osobistego i w pełni osobowego uczestniczenia w misji Kościoła, domaga się zaangażowania, które słusznie możemy nazwać „charyzmatycznym”, rozumiejąc przez to określenie w pełni osobistą odpowiedź na otrzymany dar i nadanie mu wymiaru w pełni egzystencjalnego.

W życiu Maryi widzimy syntezę tych dwóch postaw, gdy w pełni osobowo i osobiście przyjmuje Ona w sobie działanie Boże, aby potem na nie odpowiadać swoimi osobistymi wyborami. Dar Boży w niczym nie umniejsza osobowości i „osobności” Maryi, ale pozwala Jej być konkretnie i w pełni osobą oraz najbardziej owocnie, we własny sposób, pełnić powierzone Jej zadania. Wprawdzie Ewangelie niewiele mówią nam na ten temat, ponieważ wyrastają one $\mathrm{z}$ innej wrażliwości i z innej perspektywy duchowej i kulturowej, ale niewątpliwie możemy znaleźć w nowotestamentowych tekstach maryjnych sugestywne stwierdzenia, które pozwalają nam odkrywać także osobisty rys duchowości Maryi. Przede wszystkim nie jest Ona osobą bierną, tak jak nie jest bierna wiara, z którą staje Ona wobec Boga i na której opiera całe swoje życie, które może być w pełni uznane za „wędrówkę wiary”"15.

15 Por. RM 14. 
Ze spojrzenia na osobę i misję Maryi spełnioną w dziele zbawienia wynika, iż kluczową sprawą w dziele ewangelizacji pozostaje szukanie osobowej i duchowej „syntezy” wiary i łaski, która urzeczywistnia się w ścisłym łączeniu osobistego i indywidualnego udziału w tajemnicy zbawienia z jej wymiarem wspólnotowym, który stanowi jej rys charakterystyczny i w pełni właściwy. Nie należy przy tym zapominać, że jakby katalizatorem duchowym tej syntezy jest ze strony człowieka pokora, przez którą otwiera się on niejako pierwotnie na działanie Boże, jest gotowy je przyjąć i poddać mu swoje życie. Zdecydowanie za mało poświęcamy uwagi tej kluczowej postawie ludzkiej i religijnej, do której - w zasadniczym momencie swojego życia, którym jest śpiew Magnificat - odwołuje się sama Maryja, dokonując prezentacji właściwej postawy, którą zajmuje wobec Boga i która określa Jej miejsce w tajemnicy zbawienia. Trzeba by bardziej zdecydowanie pytać także w mariologii, czy na ogół pomijając to zagadnienie, nie pozbawiamy tej dziedziny teologii jednego $z$ jej najbardziej znaczących aspektów duchowych i eklezjalnych, a tym samym także siły jej oddziaływania eklezjalnego i historycznego.

\section{Wiara i jej aktualizacja eklezjalna}

Maryja poczęła swego Syna w Duchu Świętym na mocy swojej wiary, czyli - można powiedzieć - na poziomie subiektywnym i osobowym, zanim jeszcze poczęła Go w swoim łonie i porodziła jako osobowe zobiektywizowanie łaski Bożej w zmysłowym świecie czasu i przestrzeni. Kościół zdecydowanie broni swojego wymiaru instytucjonalnego, widząc w Maryi początek oficjalnej funkcji i misji Kościoła, podkreślając równocześnie i równie zdecydowanie, że jej wewnętrznym wymogiem jest świętość. Świętość osobista była niejako środowiskiem duchowym, w którym Maryja wypełniła swoją misję i zlecone Jej przez Boga zadania. Jej osobista i całkowita przynależność do Boga, dzięki Jej pełnej wolności od grzechu - co wyrażają w języku kościelnym i teologicznym najbardziej jednoznacznie przymioty: niepokalana i najświętsza - zespolonej z Jej trwałym dziewictwem, stanowi konieczną część wypełnionej przez Nią misji. 
Ten wymiar osobisty dzieła Maryi i Jej uczestniczenia w dziele zbawienia posiada równocześnie - jak już wspomnieliśmy - wymiar oficjalny. Ojcowie Kościoła bardzo mocno podkreślali w swoim nauczaniu, że Maryja porodziła Chrystusa jako Głowę Kościoła, a tym samym, że narodziny Głowy są narodzinami Kościoła. Fakt udziału Maryi w tajemnicy wcielenia posiadał więc dla nich istotny wymiar eklezjalny, stanowiąc integralną część ich eklezjogenezy. Nie stawiał on jednak Maryi „ponad” Kościołem, ale stała się Ona członkiem Kościoła, wprawdzie najbardziej szczególnym, przez co została włączona do Kościoła i do niego nieodłącznie i na trwałe należy. Bardzo znamiennym i zewnętrznym znakiem potwierdzającym ten fakt, jest po zmartwychwstaniu wyraźnie widoczne podporządkowanie się Maryi Kościołowi apostolskiemu. Jej obecność w Wieczerniku na modlitwie wraz ze wspólnotą apostolską oczekującą na zesłanie Ducha Świętego wyraźnie dowodzi, że udział Maryi w tajemnicy Słowa wcielonego nie stawia Jej ponad Kościołem, ale wyraźnie włącza Ją w Kościół, aby w nim i wraz z nim kontynuowała swój udział w tajemnicy odkupienia.

Wydaje się, że w prowadzonym dziele ewangelizacji - nawiązując do osoby i spełnionej misji Maryi - należałoby w większym stopniu zwrócić uwagę na eklezjalny wymiar wiary, gdyż tylko to gwarantuje autentyczność prowadzonego przez Kościół dzieła. Kościół nie jest jakimś zewnętrznym dodatkiem do wiary, ale jest "miejscem”, w którym następuje włączenie się $\mathrm{w}$ wiarę, będącą zawsze i pierwotnie uczestniczeniem $\mathrm{w}$ wierze Kościoła. W naszej epoce naznaczonej indywidualizmem i subiektywizmem, zachodzi potrzeba odważnego pokazywania specyfiki wiary właśnie w jej wymiarze uczestniczącym, który posiada głębokie uzasadnienia w soteriologii biblijnej. Kościół nie dostarcza tylko jakichś ram organizacyjnych wierzącym, jak często i powierzchownie się sądzi, ale stanowi żywe środowisko, w którym wiara się zaczyna, rozwija i dojrzewa, aby mogła stać się wiarą w pełni osobową i indywidualną. Oczywiście, jest to zagadnienie trudne z egzystencjalnego punktu widzenia, ale domaga się ono podjęcia właśnie $\mathrm{w}$ duchu wiary Maryi. Jej wiara jest w najwyższym stopniu wiarą kościelną, ponieważ jest wiarą uczestniczącą w doświadczeniu Starego Przymierza, prowadzącego jednoznacznie do Kościoła. Wprawdzie wiara Maryi posiada charakter uczestniczący 
w najbardziej szczególnym znaczeniu, ale niewątpliwie jest nią od początku do końca, pokazując, że do wiary w Kościół nie dochodzi się na drodze osobistego przekonania, ale od tej wiary trzeba zawsze wychodzić, aby w świetle jej trwałych treści i doświadczeń historycznych kształtować wiarę osobistą.

\section{Jedność duchowości i działania}

Jest niewątpliwym rysem wiary biblijnej, że domaga się ona szukania i efektywnego realizowania harmonijnej jedności osobowej dwóch kluczowych czynników: świętości wewnętrznej i działalności zewnętrznej: contemplatio et actio. Są to nieodzowne filary nie tylko życia kapłańskiego i zakonnego, bez których harmonijnego połączenia wszystko jest puste, ale są to także konieczne elementy życia duchowego każdego chrześcijanina, które we własny sposób, inny niż w przypadku życia kapłańskiego czy zakonnego, powinny być poszukiwane i urzeczywistniane. Jest to wewnętrzny wymóg każdej formy życia w Kościele. Stara zasada jest pewna: nie można nikomu dać tego, czego się nie posiada. Jej najprostszym, ale zarazem najmocniejszym uzasadnieniem jest odniesienie do podstawowej struktury człowieka - jest on równocześnie ciałem i duszą, stąd nie ma w nim niczego cielesnego, co nie miałoby swego wymiaru duchowego, i nie ma w nim niczego duchowego, co w jakiś sposób nie powinno potem odzwierciedlić się w ciele. Jakiekolwiek usiłowanie zmierzające do oderwania jednego elementu od drugiego albo do jakiegoś wyizolowania któregoś z nich jest skazane na porażkę, obracającą się wprost przeciw człowiekowi, ponieważ zawsze prowadzi do jakiegoś redukcjonizmu.

Wydarzenie najbardziej wyjątkowe, najbardziej znaczący akt całej ekonomii zbawienia, czyli wcielenie Słowa urzeczywistniło się w modlitewnej ciszy Nazaretu, gdzie „Słowo stało się ciałem” (J 1,14). Nawet najczystsze zamiary i pragnienia Maryi nie służyłyby niczemu, nie wyraziłyby się w faktach, gdyby nie były połączone $\mathrm{z}$ wewnętrznym otwarciem się na przychodzącego Boga i Jego działanie oraz gdyby sam Duch Święty nie stał sięźródłem Jej płodności przyjmującej wymiar cielesny. W wierze 
Maryi i w tym wszystkim, co ona za sobą pociąga, widzimy, że pierwszeństwo zostało dane modlitwie, która określa Jej strukturę wewnętrzną i stanowi podstawę Jej działań, które przechodzą potem na poziom zewnętrzny. Bardzo dobrze uchwyciła ten fakt ikonografia kościelna, która ukazując moment zwiastowania, widzi Maryję w postawie modlitwy, określając w ten sposób niejako Jej tożsamość jako Orantki - Virgo orans ${ }^{16}$.

$\mathrm{Z}$ tego ukierunkowania wewnętrznego na Boga rodziły się czyny Maryi, formując jedną, harmonijną i spójną rzeczywistość. Jej życie wewnętrzne zwracało się do Boga i było wołaniem o Niego i Jego udzielanie się, aby Jej działanie zewnętrzne mogło stać się wcieleniem łaski, osiągającej najwyższy wyraz w uczestniczeniu przez wiarę i miłość w krzyżu Chrystusa, tak że może być nazywana Królową męczenników. Możemy powiedzieć, że Maryja dzięki swojej jedynej w swoim wyrazie duchowości prowadzi do egzystencjalnego urzeczywistnienia zasadę sformułowaną przez św. Tomasza z Akwinu: Deus non dat gratiam homini nisi utatur illa - „Bóg daje łaskę tylko po to, aby jej używać” ${ }^{17}$. W przypadku Maryi można powiedzieć, że nie tylko wykorzystuje Ona daną Jej łaskę, ale rzeczywiście ją wciela. Używanie łaski, której Bóg udziela człowiekowi, jest uwarunkowane stanem ducha człowieka i na gruncie ducha zyskuje ono pełne urzeczywistnienie jako jej wcielenie.

Ponieważ Maryja w Duchu Świętym pozostaje w osobowej, wewnętrznej i głębokiej komunii z Bogiem, z tej racji odnajduje Go i wyraża na ludzki sposób we wszystkim, co robi. Ta komunia rozciąga się na Jej serce i na Jej czyny, dlatego nie ma, choćby najmniejszego dualizmu w Jej życiu - urzeczywistnia Ona ten ideał, który dzisiaj chętnie nazywamy „jednością życia” i czego poszukujemy, nawet nie w pełni świadomie.

Łaska prowadzi do działania, a działanie woła o łaskę. Aby jednak to wołanie okazało się skuteczne, domaga się ono odpowiedniego ukształtowania serca, którego szkołą jest przede wszystkim modlitwa. Z tej zasady, która ma jednoznaczne uzasadnienie maryjne, trzeba też wyprowadzić wnioski o charakterze ewangelizacyjnym. To wielkie dzieło może

16 Por. G. Santambrogio, Annunciazione. Le più belle rappresentazioni dellarte, Novara 2006.

17 Tomasz z Akwinu, In psalmos Davidis expositio, 38, 1. 
być urzeczywistniane i może przynosić owoce tylko i wyłącznie w maryjnym klimacie jedności modlitwy i działania. Ta prawda, bardzo dobrze znana od wieków, domaga się tym bardziej zdecydowanej i dopracowanej aktualizacji, im bardziej duchowe zadania na nas spoczywają i im stają się trudniejsze do wypełnienia w dzisiejszym świecie. Z taką sytuacją na pewno mamy do czynienia w dzisiejszym zsekularyzowanym świecie, który będąc jednostronnie nastawiony na podkreślanie i widzenie „,sprawczości" ludzkich czynów, zapomina o ich duchowych podstawach i uwarunkowaniach. Z takim zapomnieniem spotykamy się niejednokrotnie także w Kościele i w prowadzonych przez niego poszukiwaniach i działaniach o charakterze ewangelizacyjnym.

Z jednością wewnętrzną modlitwy i czynu ściśle łączy się dzisiaj także bardzo ważne zagadnienie jedności ducha i normy zewnętrznej (prawa). W wielu przypadkach zauważamy na przykład realne przeciwstawianie ducha prawu, charyzmatu instytucji, wolności władzy itd. Wkrada się w doświadczenie kościelne pewna dychotomia, która nie zawsze spotyka się z należytą reakcją i z wyjaśnieniem. Nacisk ze strony instancji "zewnętrznych", zwłaszcza prawno-instytucjonalnych, z którym mamy do czynienia w dzisiejszym życiu publicznym, który nie przynosi jednak oczekiwanych rezultatów odnowy i konsolidacji społecznej, powoduje pewne odreagowanie, które do pewnego stopnia najłatwiej jest proponować i realizować w życiu religijnym, polegające na odrzuceniu wszystkiego tego, co instytucjonalne. Widać to na pewno w wielu obszarach życia duchowego zdominowanego przez tak zwane ruchy czy nurty charyzmatyczne, które wręcz histerycznie reagują na wszelkie propozycje pewnego sformalizowania ich struktur i działan. Oczywiście, nie jest to jedyna przyczyna zjawiska, ale sądzę, że ma ona kluczowe znaczenie i wywiera dominujący wpływ. W każdym jednak razie pozostaje faktem, że trzeba poszukiwać kanonicznego odniesienia do siebie darów hierarchicznych i charyzmatycznych, gdyż tego domaga się wewnętrzna struktura Kościoła ${ }^{18}$.

18 Por. G. Ghirlanda, Forme canoniche di riconosciemnto dei doni carismatici, w: Congregazione per la Dottrina della Fede, La lettera „Iuvenescit Ecclesia” ai Vescovi della Chiesa Cattolica sulle relazioni tra doni gerarchici e carismatici per la vita e la missione della Chiesa, Città del Vaticano 2019, s. 73-82. 
Także w tym przypadku odwołanie się do osoby i doświadczenia Maryi może być bardzo konstruktywne i ukierunkowujące. Maryja dała Słowu ciało, a tym samym Słowo wcielone przyjęło to podstawowe ograniczenie, którym jest ciało ziemskie. Mimo tego ograniczenia, a bardziej właściwie mówiąc - właśnie za pośrednictwem tego ograniczenia, Jezus Chrystus manifestuje swoją pełną wolność duchową i pokazuje drogę jej urzeczywistniania. Poddanie się ciału, prawu, rozmaitym przepisom, obyczajom religijnym i zwyczajom kulturowym, a więc temu wszystkiemu, co zewnętrzne, nie wpłynęło w najmniejszym stopniu na wolność Chrystusa, stając się żywym i konstytutywnym środowiskiem, w którym ta wolność się wyraziła, a tym samym dokonała odkupienia wszelkich ograniczeń, którym podlega człowiek. Maryja, Matka Chrystusa, jest nie tylko pewnym „elementem” tego ograniczenia się przez wcielone Słowo, ale ze względu na jego funkcję zbawczą uczestniczy także w Jego wolności i pokazuje, że nic nie może jej ograniczyć, jeśli jest ona wolnością przeżywaną $\mathrm{w}$ wierze i $\mathrm{w}$ poddaniu się Bogu.

Możemy wyprowadzić $\mathrm{z}$ tego ważny wniosek, a mianowicie musimy stwierdzić, że prawdziwy duch autentycznej ewangelizacji nie jest pozbawiony kontroli, nie jest udziałem nieograniczonych niczym entuzjastów, ale jest duchem zdecydowanym i uporządkowanym, zdającym sobie sprawę z istniejących zasad i kryteriów, a tym samym wpisującym się w ramy pewnego porządku, który także posiada wymiar soteriologiczny. Instytucjonalny wymiar Kościoła nie jest jakimś „złem koniecznym”, ale dobrem zbawczym. Duch ewangeliczny ma odwagę zaangażować się w pełni w ciele na polu tego, co skończone i konkretne. Kto wychodzi poza pewne ograniczenia ustalone przez Kościół - ustalone nie arbitralnie, ale na podstawie wielowiekowych doświadczeń - nie kieruje się Duchem Bożym. Poddanie się normie kościelnej i inspirowanie się nią jest podstawową cechą charakterystyczną autentycznego ducha apostolskiego, a przez to także zyskuje gwarancję skuteczności soteriologicznej. Jest prawdą, że litera zabija ducha, ale duch bez litery łatwo ulega fantazjom i zostaje poddany niebezpiecznemu odcieleśnieniu, a tym samym schodzi na błędne drogi gnozy albo aktywizmu, w którym działanie staje się celem samym w sobie. Prawo w Kościele jest wcieleniem ducha - dotyczy to także wszelkich form i postaci ewangelizacji prowadzonej w Kościele i przez Kościół. 


\section{Zakończenie}

Wskazane wyżej aspekty praurzeczywistnienia Kościoła w Maryi oraz próba ich odczytania w relacji do misji ewangelizacyjnej nie wyczerpują oczywiście zagadnienia, choć wydaje się, że pozwalają one dość wyraźnie zauważyć, że można mówić o maryjnym wymiarze i maryjnej strukturze ewangelizacji. W ramach podjętego tutaj zagadnienia na pewno można by jeszcze uwzględnić następujące elementy maryjne, które poszerzyłyby postawiony w tym artykule główny problem: jedność misji ewangelizacyjnej i świadectwa - Maryja świadek; konsekwencja w pełnionej misji ewangelizacyjnej - Maryja jest Matką Syna Bożego przez całe życie; ewangelizacja przez krzyż i pod krzyżem - ewangelizacyjne współcierpienie z Maryją; wyczekanie na moment Boży - odpowiedniość wybranej przez wiarę chwili głoszenia i działania. Wszystkie te elementy mogłyby zostać rozjaśnione w perspektywie maryjnej, ponieważ należą one integralnie do misji spełnionej przez Maryję w dziejach zbawienia.

W tym miejscu pozostaje jednak zauważyć, że odniesienie do Maryi jako typus Ecclesiae ma i może mieć w jeszcze większym stopniu realne znaczenie zarówno dla rozumienia natury i ostatecznego wypełnienia Kościoła, jak dla kształtowania jego misji ewangelizacyjnej. Maryja na pewno „nie przysłania” Chrystusa, jak twierdzi się niekiedy, ale ukazuje Go wierzącym, ucząc także Kościół, w jaki sposób może i powinien skutecznie pełnić zleconą mu misję zbawczą. Jest więc sensowne odwoływanie się w teologii oraz w pobożności i duchowości do Maryi jako Gwiazdy ewangelizacji.

\section{Bibliografia}

Fisichella R., La nova evangelizzazione. Una sfida per uscire dall'indifferenza, Milano 2011.

Ghirlanda G., Forme canoniche di riconosciemnto dei doni carismatici, w: Congregazione per la Dottrina della Fede, La lettera „Iuvenescit Ecclesia” ai Vescovi della Chiesa Cattolica sulle relazioni tra doni gerarchici e carismatici per la vita e la missione della Chiesa, Città del Vaticano 2019, s. 73-82. 
Jan Damasceński, De fide orthodoxa: PG 94, 789-1227.

Jan Paweł II, Encyklika Redemptoris Mater, Rzym 1987.

Jan Paweł II, List apostolski Mulieris dignitatem, Rzym 1988.

Kongregacja Nauki Wiary, Instrukcja o chrześcijańskiej wolności i wyzwoleniu Libertatis conscientia (22 marca 1986 r.), w: J. Królikowski, Z. Zimowski (red. i tłum.), W trosce o pełnię wiary. Dokumenty Kongregacji Nauki Wiary 1966-1994, Tarnów 2010, s. 291-336.

Królikowski J., Kościół w Jezusie Chrystusie. Chrystologiczno-pneumatologiczna geneza Kościoła, Kraków 2015.

Królikowski J., Maryja - Gwiazda ewangelizacji, w: Idźcie i głoście. Przez Chrystusa, z Chrystusem, w Chrystusie. Przez wiarę i chrzest do świadectwa. Program duszpasterski Kościoła w Polsce na lata 2013-2017, Poznań 2016, s. 353-369.

Lubac H. de, Katolicyzm. Społeczne aspekty dogmatu, tłum. M. Stokowska, Kraków 1988.

Rahner H., Maria e la Chiesa. Indicazioni per contemplare il mistero di Maria nella Chiesa e il mistero della Chiesa in Maria, Milano 1991.

Santambrogio G., Annunciazione. Le più belle rappresentazioni dellarte, Novara 2006.

Scaglioni C., Synkatabasis. La condiscendenza divina in Giovanni Crisostomo, Trapani 2011.

II Sobór Watykański, Konstytucja dogmatyczna o Kosciele Lumen gentium, Rzym 1964.

Tomasz z Akwinu, In psalmos Davidis expositio.

Ks. prof. dr hab. Janusz Królikowski - kapłan diecezji tarnowskiej; od 2014 roku dziekan Wydziału Teologicznego Sekcja w Tarnowie (UPJPII). W latach 1991-1996 studiował teologię na uczelniach rzymskich: Papieskim Uniwersytecie Świętego Krzyża (doktorat w 1995 roku), Papieskim Instytucie Wschodnim, Instytucie św. Tomasza Uniwersytetu Angelicum. W 2003 roku habilitował się w zakresie teologii dogmatycznej w Papieskiej Akademii Teologicznej w Krakowie. W latach 1996-2009 wykładał teologię w Papieskim Uniwersytecie Świętego Krzyża w Rzymie, a od 1997 roku wykłada teologię dogmatyczną na Wydziale Teologicznym Sekcja w Tarnowie. Od 2010 roku wykładowca mariologii 
w Instytucie Maryjno-Kolbiańskim „Kolbianum” w Niepokalanowie. Członek Polskiego Towarzystwa Mariologicznego, Towarzystwa Teologów Dogmatyków, Polskiego Towarzystwa Teologicznego Oddział w Tarnowie, członek zwyczajny Międzynarodowej Papieskiej Akademii Maryjnej w Rzymie. Autor licznych publikacji teologicznych. 